\title{
Effect of Carbon, Nitrogen, and C:N Ratio on Growth, Sporulation, and Biocontrol Efficacy of Talaromyces flavus
}

\author{
C. A. Engelkes, R. L. Nuclo, and D. R. Fravel
}

Biocontrol of Plant Diseases Laboratory, Plant Sciences Institute, Agricultural Research Service, U.S. Department of Agriculture, Beltsville, MD 20705.

C. A. Engelkes is deceased.

Accepted for publication 5 February 1997.

\begin{abstract}
Engelkes, C. A., Nuclo, R. L., and Fravel, D. R. 1997. Effect of carbon, nitrogen, and $\mathrm{C}: \mathrm{N}$ ratio on growth, sporulation, and biocontrol efficacy of Talaromyces flavus. Phytopathology 87:500-505.

Five-day biomass production by the biocontrol fungus Talaromyces flavus was measured in a liquid basal medium, $\mathrm{pH} 5.5$, containing each of 37 carbon $(\mathrm{C})$ sources with a single nitrogen $(\mathrm{N})$ source, and each of 42 $\mathrm{N}$ sources with a single $\mathrm{C}$ source. In general, production of biomass was greatest on complex sugars such as polysaccharides $(32 \mathrm{~g} /$ liter of medium) and $\beta$-glucosides ( $2.4 \mathrm{~g} /$ liter of medium), and was least on monosaccharides (1.3 g/liter of medium). Ascospore production at 6 weeks on solid basal medium with the same amount of these same $37^{\circ} \mathrm{C}$ sources was greatest on oligosaccharides $\left(2.9 \times 10^{8}\right.$ spores per 5.5 -cm-diameter petri dish), and least on polysaccharides and monosaccharides (1.6 and $1.4 \times 10^{8}$ spores per 5.5-cm-diameter petri dish, respectively). For C

5.5-cm-diameter petri dish and $10^{-4}$ to $10^{-5} \mathrm{~g}$ of hyphal dry weight per milliliter. In general, $\mathrm{N}$ sources that resulted in the greatest number of ascospores also yielded the greatest hyphal dry weights. For the two $\mathrm{C}$ and two $\mathrm{N}$ sources tested, the number of ascospores increased as the ratio of $\mathrm{C}$ to $\mathrm{N}$ increased from $5: 1$ to $30: 1$. This effect was most obvious as the $\mathrm{C}: \mathrm{N}$ ratio increased from $5: 1$ to $15: 1$. At low $\mathrm{C}: \mathrm{N}$ ratios $(<15: 1)$, treatments with hypoxanthine as a $\mathrm{N}$ source resulted in significantly greater production of biomass than treatments with ammonium tartrate; no difference was observed at $\mathrm{C}: \mathrm{N}$ ratios $\geq 15: 1$. Incidence of Verticillium wilt was $50 \%$ lower for eggplants drenched with ascospores grown on potato dextrose agar (PDA) compared with eggplants either nondrenched or drenched with ascospores grown on media with hypoxanthine plus lactose or maltose. Thus, $\mathrm{C}$ and $\mathrm{N}$ sources that slightly increased ascospore production of $T$. flavus reduced efficacy of biocontrol of Verticillium wilt compared with ascospores produced on PDA.
\end{abstract} sources, there was no correlation between production of ascospores and hyphal dry weight. The various $\mathrm{N}$ sources yielded 0 to $10^{9}$ ascospores per

Talaromyces flavus (Klöcker) A.C. Stolk \& R.A. Samson is a promising biocontrol fungus against wilt diseases of eggplant (10), potato $(3)$, tomato $(14,16)$, artichoke $(17)$, and olive $(15,16)$ caused by Verticillium dahliae (Kleb.). To mass produce T. flavus for use in biocontrol, information is needed on the effects of carbon (C) and nitrogen $(\mathrm{N})$ sources on ascospore and biomass production. Further, since control with $T$. flavus can be inconsistent and the level of control currently provided by $T$. flavus may not be adequate to justify its development as a commercial product, we are investigating ways of improving the performance of T. flavus. One way to enhance performance of $T$. flavus may be through manipulation of nutrients present in production and formulation of the antagonist. The objectives of this nutritional study of $T$. flavus were to determine the effect of $\mathrm{C}$ and $\mathrm{N}$ source and ratio on biomass and ascospore production, and to determine biocontrol efficacy of ascospores produced on three media against Verticillium wilt of eggplant.

\section{MATERIALS AND METHODS}

Fungi. T. flavus isolate Tf-1 (10) was used in all experiments. Stock cultures were grown on potato dextrose agar (PDA) (Difco

Corresponding author: D. R. Fravel; E-mail address: dfravel@asrr.arsusda.gov

Mention of a trademark or proprietary product does not constitute a guarantee or warranty of the product by the U.S. Department of Agriculture, and does not imply its approval to the exclusion of other products that may also be suitable.

Publication no. P-1997-0304-02R

This article is in the public domain and not copyrightable. It may be freely reprinted with customary crediting of the source. The American Phytopathological Society, 1997.
Additional keywords: Solanum melongena, Verticillium dahliae.

Laboratories, Detroit) in the dark at $27^{\circ} \mathrm{C}$. For the biocontrol efficacy experiments, microsclerotia of $V$. dahliae isolate $\mathrm{V}-1$ (4) were produced on Czapek solution agar (CA) (Difco Laboratories) in the dark at $21^{\circ} \mathrm{C}$.

Media. The basal medium had a $\mathrm{C}: \mathrm{N}$ ratio of $6.85: 1$ and contained per liter $20 \mathrm{~g}$ of maltose, $5 \mathrm{~g}$ of ammonium tartrate, $1 \mathrm{~g}$ of $\mathrm{NH}_{4} \mathrm{NO}_{3}, 1 \mathrm{~g}$ of $\mathrm{KH}_{2} \mathrm{PO}_{4}, 0.5 \mathrm{~g}$ of $\mathrm{MgSO}_{4} \cdot 7 \mathrm{H}_{2} \mathrm{O}, 0.1 \mathrm{~g}$ of $\mathrm{NaCl}$, $0.1 \mathrm{~g}$ of $\mathrm{CaCl}_{2}, 1 \mathrm{ml}$ of Pridham and Gottlieb trace salts $(0.64 \mathrm{~g}$ of $\mathrm{CuSO}_{4} \cdot 5 \mathrm{H}_{2} \mathrm{O}, 0.11 \mathrm{~g}$ of $\mathrm{FeSO}_{4} \cdot 7 \mathrm{H}_{2} \mathrm{O}, 0.79 \mathrm{~g}$ of $\mathrm{MnCl}_{2} \cdot 4 \mathrm{H}_{2} \mathrm{O}$, and $0.15 \mathrm{~g}$ of $\mathrm{ZnSO}_{4} \cdot 7 \mathrm{H}_{2} \mathrm{O}$ ), and $100 \mathrm{ml}$ of distilled water (12). Initial $\mathrm{pH}$ of the amended basal medium in each experiment was adjusted to 5.5 with $1 \mathrm{~N} \mathrm{HCl}$ or $1 \mathrm{~N} \mathrm{NaOH}$ and autoclaved at $121^{\circ} \mathrm{C}$ for $20 \mathrm{~min}$. A 5-mm-diameter sterile cork borer was used to cut disks from a 2-week-old culture of Tf-1 grown on PDA. Agar disks were transferred to a sterile blender container with $7 \mathrm{ml}$ of sterile distilled water added for each disk, resulting in approximately $2 \times 10^{5}$ ascospores/ml plus hyphal fragments (8). The mixture was homogenized for $45 \mathrm{~s}$. Sufficient amount of Tf-1 inoculum was prepared for each replication per experiment.

C sources. The basal medium was prepared in $125-\mathrm{ml}$ aliquots with $2 \%$ by weight of each of 37 monosaccharides, oligosaccharides, polysaccharides, and $\beta$-glucosides as the primary $C$ source in place of maltose (Table 1). Ammonium tartrate supplied $1.3 \mathrm{~g}$ of $\mathrm{C} /$ liter in the basal medium. The basal medium without maltose was included as a control, as was a treatment with no $\mathrm{C}$ source, which was not inoculated. No growth was observed in the noninoculated control, and this treatment was not included in data analysis.

For determination of biomass production, $20 \mathrm{ml}$ of a medium dispensed into each $25 \times 200$-mm test tube was autoclaved and equilibrated to $27^{\circ} \mathrm{C}$ overnight. After which, $1.0 \mathrm{ml}$ of $T$. flavus 
suspension was pipetted into each test tube. Test tubes were covered with plastic caps and Parafilm, and then placed at a $45^{\circ}$ angle in a wire basket, and baskets were placed on a shaker. Cultures of T. flavus were grown for 5 days in the dark at $27^{\circ} \mathrm{C}$ with shaking at $1,000 \mathrm{rpm}$. Fungal biomass in each test tube was collected by vacuum filtration onto oven-dried, tared, 9-cm filter paper (Whatman \#2; Whatman International, Ltd., Maidstone, England), washed with distilled water, and dried at $95^{\circ} \mathrm{C}$ for 3 days. Treatments were replicated four times in each of two trials.

Forty-five milliliters of liquid medium for each treatment above was not used for the biomass study. Immediately after preparation of these media, $0.9 \mathrm{~g}$ of agar was added to the $45 \mathrm{ml}$ remaining from each treatment and the $\mathrm{pH}$ again adjusted to 5.5 before autoclaving. Ten milliliters of a medium was dispensed into each of four $60 \times 15$-mm petri dishes and equilibrated to $27^{\circ} \mathrm{C}$ overnight. Each dish was inoculated with $0.5 \mathrm{ml}$ of a $T$. flavus suspension and incubated in the dark at $27^{\circ} \mathrm{C}$. Dishes were inverted 3 days after inoculation. After 6 weeks, cleistothecia were scraped from the surface of the agar. The agar surface was then rinsed with 10 $\mathrm{ml}$ of distilled water. Ascospore suspensions were comminuted for $30 \mathrm{~s}$ in an Omni-mixer (Ivan Sorvall, Inc., Norwalk, CT) containing $15 \mathrm{ml}$ of distilled water (DW). After diluting this suspension with $25 \mathrm{ml}$ of DW, ascospore concentrations per milliliter were determined with a hemacytometer. Concentrations of conidia also were determined when conidia were produced in culture. Treatments were replicated three times in each of two trials with each petri dish considered a replicate.

Analyses of variance and mean separations of biomass dry weight and ascospore concentration data were performed with the Statistical Analysis System (SAS Institute, Inc., Cary, NC) analysis of variance procedure (ANOVA) with mean separation by Tukey's studentized test. C sources were classified by biochemical grouping (Table 1). Mean separations were performed with the individual $\mathrm{C}$ sources and by biochemical groupings.

N sources. The basal medium, with maltose as the $\mathrm{C}$ source, was prepared with each of $42 \mathrm{~N}$ sources (Table 2) added in an amount equivalent to the $1.1 \mathrm{~g}$ of $\mathrm{N} /$ liter previously contributed by ammonium tartrate and $\mathrm{NH}_{4} \mathrm{NO}_{3}$. The basal media without a $\mathrm{N}$ source, inoculated and noninoculated, were included as control treatments. No growth was observed in the noninoculated control, and this treatment was not included in the analysis. Effect of $\mathrm{N}$ sources on biomass and ascospore production was tested and analyzed as previously described.

Daily biomass production and media pH. From 0 to 5 days after inoculation, daily growth rates of $T$. flavus in 12 media and changes in $\mathrm{pH}$ were determined at $27^{\circ} \mathrm{C}$ and ambient temperature ( 22 to $26^{\circ} \mathrm{C}$ ). To evaluate the effect of six $\mathrm{C}$ sources, the basal medium was amended with $2 \%$ by weight of glycerol, gum ghatti, lactose, maltose, sorbose, or xylan (oat spelts) as the $\mathrm{C}$ source and $1.1 \mathrm{~g}$ of $\mathrm{N} /$ liter of ammonium tartrate or $\mathrm{NH}_{4} \mathrm{NO}_{3}$ as the $\mathrm{N}$ source. No $\mathrm{C}$ was added to the control treatment. To evaluate the effect of six $\mathrm{N}$ sources, the basal medium was amended with $2 \%$ by weight of maltose as the $\mathrm{C}$ source and $1.1 \mathrm{~g}$ of N/liter of ammonium tartrate, anthranilic acid, hypoxanthine, L-methionine, L-threonine, or L-tyrosine as the $\mathrm{N}$ source. No $\mathrm{N}$ was added to the control treatment. Biomass production in each of two test tubes per medium and temperature were measured and compared with the controls, as previously described. The $\mathrm{pH}$ of the medium, in each test tube from which the biomass was collected, was recorded. Biomass dry weights and $\mathrm{pH}$ data were expressed as average values of four replicate cultures across temperature in each of two trials.

$\mathrm{C}: \mathrm{N}$ ratios and PDA. The basal medium was prepared with a concentration of $9 \mathrm{~g}$ of $\mathrm{C}$ per liter and $\mathrm{C}: \mathrm{N}$ ratios of 5:1, 10:1, $15: 1,20: 1,25: 1$, and 30:1. Maltose $(39 \% \mathrm{C})$ or lactose $(40 \% \mathrm{C})$ was the primary $\mathrm{C}$ source, and hypoxanthine $(44 \% \mathrm{C}$ and $41 \% \mathrm{~N})$ or ammonium tartrate $(26 \% \mathrm{C}$ and $15 \% \mathrm{~N})$ was the $\mathrm{N}$ source.
Biomass dry weights in five replications and ascospore and conidia numbers in three replications were determined as previously described. Experiments were repeated once.

Biocontrol efficacy. The effect of three media on the potential ascospores produced on these media to control Verticillium wilt of eggplant (Solanum melongena L.) was determined in the greenhouse. Ascospores of T. flavus were produced in the dark at $27^{\circ} \mathrm{C}$ on PDA and on basal medium amended with agar and a 15:1 C:N ratio of either maltose or lactose and hypoxanthine, as previously described. Ascospore suspensions, which contained approximately $10^{6}$ ascospores per milliliter, were prepared from 6-week-old cultures.

Eggplant seeds (cv. Black Beauty; Harris Seed, Rochester, NY) were planted in 9-cm-diameter pots containing approximately 100 $\mathrm{g}$ of soilless potting mix (Pro-Mix BX; Premier Brands, Inc., New

TABLE 1. Production of ascospores of Talaromyces flavus on solidified media after 6 weeks, hyphae in liquid media after 5 days, and final $\mathrm{pH}$ of basal media supplemented with various carbon sources

\begin{tabular}{|c|c|c|c|c|c|}
\hline Carbon & Class $^{\mathrm{a}}$ & Ascospores $^{b}$ & $\begin{array}{l}\text { Hyphal dry } \\
\text { weight }^{\mathrm{c}}\end{array}$ & $\begin{array}{c}\text { Final } \\
\mathrm{pH}\end{array}$ & Source $^{\mathrm{d}}$ \\
\hline D-lactose monohydrate $\mathrm{ACS}^{\mathrm{e}}$ & $\mathrm{O}$ & 7.56 & 0.15 & 5.65 & $\mathrm{~S}$ \\
\hline Glycerol, anhydrous & M & 6.40 & 0.3 & 5.6 & B \\
\hline $\begin{array}{l}\text { D-arbutin, synthetic } \\
\text { crystalline }\end{array}$ & G & 6.13 & 0.53 & 5.33 & $\mathrm{~S}$ \\
\hline $\begin{array}{l}\text { Cellulose, type } 20 \\
\text { microcrystalline }\end{array}$ & $\mathrm{P}$ & 5.95 & 5.76 & 5.3 & $\mathrm{~S}$ \\
\hline Cellulose, microgranular & $\mathrm{P}$ & 5.61 & 3.95 & 5.44 & $\mathrm{~S}$ \\
\hline Phloridzin dihydrate & G & 3.79 & 8.06 & 5.21 & $\mathrm{~S}$ \\
\hline D-melibiose & $\mathrm{O}$ & 3.66 & 0.97 & 4.71 & $\mathrm{~S}$ \\
\hline D-cellobiose & $\mathrm{O}$ & 2.39 & 2.49 & 4.25 & $\mathrm{~S}$ \\
\hline D-trehalose, dihydrate & $\mathrm{O}$ & 2.32 & 2.36 & 4.3 & $\mathrm{~N}$ \\
\hline D-raffinose & $\mathrm{O}$ & 2.19 & 1.66 & 4.57 & $\mathrm{~S}$ \\
\hline Methyl- $\beta$-D-glucopyranoside & G & 2.1 & 2.35 & 4.5 & $\mathrm{~S}$ \\
\hline L-rhamnose & M & 2.09 & 1.16 & 4.51 & $\mathrm{~N}$ \\
\hline L-sorbose & M & 1.55 & 0.17 & 4.96 & I \\
\hline Cellulose, medium fibrous & $\mathrm{P}$ & 1.55 & 2.29 & 5.48 & $\mathrm{~S}$ \\
\hline $\begin{array}{l}\text { D-maltose monohydrate, } \\
\text { grade I }\end{array}$ & $\mathrm{O}$ & 1.33 & 3.48 & 4.32 & $\mathrm{~S}$ \\
\hline D-galactose, purified grade & M & 1.19 & 0.71 & 5.03 & $\mathrm{~S}$ \\
\hline D-xylose & M & 1.13 & 2.42 & 4.38 & B \\
\hline D-ribose & M & 1.06 & 1.21 & 4.69 & $\mathrm{~S}$ \\
\hline$N$-acetyl-D-glucosamine & M & 0.97 & 0.58 & 5.78 & $\mathrm{~S}$ \\
\hline L-arabinose & M & 0.90 & 1.31 & 4.63 & $\mathrm{~S}$ \\
\hline D-fructose & M & 0.89 & 2.33 & 4.28 & $\mathrm{~S}$ \\
\hline Pectin (apple) & $\mathrm{P}$ & 0.79 & 1.4 & 3.90 & $\mathrm{~S}$ \\
\hline $\begin{array}{l}\text { Chitin (to pass } 0.25-\mathrm{mm} \\
\text { opening) }\end{array}$ & $\mathrm{P}$ & 0.74 & 4.93 & 5.98 & $\ldots$ \\
\hline Gum ghatti & $\mathrm{P}$ & 0.72 & 4.54 & 5.19 & $\mathrm{~S}$ \\
\hline Xylan (oat spelts) & $\mathrm{P}$ & 0.70 & 8.73 & 4.46 & $\mathrm{~S}$ \\
\hline D-mannose & M & 0.70 & 2.97 & 4.31 & $\mathrm{~S}$ \\
\hline Carboxymethylcellulose & $\mathrm{P}$ & 0.69 & 0.63 & 5.39 & $\mathrm{~N}$ \\
\hline D-sucrose ACS reagent & $\mathrm{O}$ & 0.68 & 2.39 & 4.31 & $\mathrm{~S}$ \\
\hline D-glucose, grade III & M & 0.62 & 2.36 & 3.40 & $\mathrm{~S}$ \\
\hline Gum arabic & $\mathrm{P}$ & 0.60 & 0.74 & 5.45 & $\mathrm{~F}$ \\
\hline D-glucuronic acid & M & 0.47 & 0.71 & 6.28 & $\mathrm{~S}$ \\
\hline $\begin{array}{l}\text { D-galacturonic acid } \\
\text { monohydrate }\end{array}$ & M & 0.43 & 0.39 & 6.54 & $\mathrm{~S}$ \\
\hline Chitin, bleached (to pass & & & & & \\
\hline 0.355-mm opening) & $\mathrm{P}$ & 0.29 & 2.46 & 6.20 & $\mathrm{~S}$ \\
\hline Pectin (citrus) & $\mathrm{P}$ & 0.25 & 1.72 & 3.92 & $\mathrm{~S}$ \\
\hline Salicin & G & 0.19 & 0.56 & 5.32 & $\mathrm{~S}$ \\
\hline Polygalacturonic acid & $\mathrm{P}$ & 0.17 & 0.80 & 5.20 & $\mathrm{~S}$ \\
\hline Phenyl- $\beta$-D-glucoside & G & 0.11 & 0.45 & 5.05 & $\mathrm{~S}$ \\
\hline None & $\ldots$ & 0.01 & 0.16 & 5.23 & $\ldots$ \\
\hline $\operatorname{LSD}(P \leq 0.05)$ & $\ldots$ & 1.63 & 2.11 & 0.17 & $\ldots$ \\
\hline
\end{tabular}

${ }^{a} \mathrm{M}=$ monosaccharide, $\mathrm{O}=$ oligosaccharide, $\mathrm{P}=$ polysaccharide, and $\mathrm{G}=\beta$ glucoside.

b In 5.5-cm-diameter petri dish $\left(\times 10^{8}\right)$.

c Measured as $\mathrm{g} / \mathrm{ml}\left(\times 10^{-3}\right)$.

${ }^{\mathrm{d}} \mathrm{B}=\mathrm{J}$. T. Baker Inc. (Phillipsburg, NJ), F = Fisher Scientific Co. (Pittsburgh), I = ICN Pharmaceuticals (Costa Mesa, CA), N = National Biochemicals (Cleveland), and S = Sigma Chemical Co. (St. Louis).

e ACS = American Chemical Society. 
Rochelle, NY). To establish high populations of the biocontrol fungus $T$. flavus in the potting mix before eggplants were exposed to $V$. dahliae, $10 \mathrm{ml}$ of an ascospore suspension was applied to the soil in each of 15 pots per treatment at $0,2,4,6$, and 8 weeks after planting. Ten milliliters of DW was applied to the soil in each of 15 pots for the two control treatments. The healthy control had neither T. flavus nor $V$. dahliae, and the disease control had $V$. dahliae only.

At 8 weeks after planting, Rumford loamy sand soil $(74.3 \%$ sand, $8.6 \%$ silt, $17.1 \%$ clay, and $0.3 \%$ humic matter, $\mathrm{pH} 4.5$ ) was artificially infested with $25 \mathrm{~V}$. dahliae microsclerotia/g of fresh weight soil. Soil was collected from the field the day prior to use and was screened through a $0.5 \times 0.5-\mathrm{cm}$ pore size screen to remove rocks and plant debris. Microsclerotia of $V$. dahliae were produced after 4 to 5 weeks on CA. Microsclerotia in the top 0.5 $\mathrm{cm}$ of agar were comminuted in $150 \mathrm{ml}$ of DW for $1 \mathrm{~min}$, and numbers determined with an eosinophil counter. To distribute the inoculum uniformly in soil for potting, microsclerotia were first mixed with $6 \mathrm{~kg}$ of soil in a mixer (Hobart Corp., Troy, OH) for

TABLE 2. Production of ascospores of Talaromyces flavus on solidified media after 6 weeks, hyphae in liquid media after 5 days, and final $\mathrm{pH}$ of basal media supplemented with various nitrogen sources

\begin{tabular}{|c|c|c|c|c|}
\hline Nitrogen & Ascospores ${ }^{\mathrm{a}}$ & $\begin{array}{c}\text { Hyphal dry } \\
\text { weight }^{\mathrm{b}}\end{array}$ & $\begin{array}{c}\text { Final } \\
\mathrm{pH}\end{array}$ & Source ${ }^{c}$ \\
\hline Calcium nitrate & 11.42 & 2.43 & 5.03 & $\mathrm{~S}$ \\
\hline Uric acid & 10.15 & 3.87 & 4.47 & $\mathrm{~S}$ \\
\hline Xanthine & 9.91 & 2.73 & 4.17 & $\mathrm{~S}$ \\
\hline L-ornithine hydrochloride & 9.53 & 2.73 & 3.02 & $\mathrm{~S}$ \\
\hline L-tyrosine & 9.11 & 8.20 & 3.92 & $\mathrm{~S}$ \\
\hline Inosine & 9.04 & 2.72 & 4.24 & $\mathrm{~S}$ \\
\hline Guanine & 8.43 & 3.06 & 4.53 & $\mathrm{~S}$ \\
\hline Hypoxanthine & 7.29 & 3.93 & 4.20 & $\mathrm{~S}$ \\
\hline Allantoin & 6.89 & 2.53 & 3.46 & $\mathrm{~S}$ \\
\hline L-tryptophane & 4.16 & 2.21 & 3.72 & $\mathrm{~F}$ \\
\hline L-phenylalanine & 3.14 & 2.09 & 3.94 & $\mathrm{~S}$ \\
\hline Ammonium nitrate & 1.39 & 1.52 & 2.71 & $\mathrm{~S}$ \\
\hline None & 1.28 & 0.47 & 3.82 & $\ldots$ \\
\hline L-valine & 1.19 & 2.90 & 3.89 & $\mathrm{E}$ \\
\hline Potassium nitrate & 1.15 & 2.49 & 5.37 & $\mathrm{~S}$ \\
\hline L-isoleucine & 0.87 & 2.61 & 4.23 & $\mathrm{~S}$ \\
\hline L-leucine & 0.84 & 2.18 & 4.15 & $\mathrm{~S}$ \\
\hline L-lysine monohydrochloride & 0.29 & 1.30 & 3.23 & $\mathrm{~S}$ \\
\hline Ammonium sulfate & 0.29 & 1.33 & 2.81 & $\mathrm{~S}$ \\
\hline Adenine & 0.26 & 3.70 & 4.39 & $\mathrm{~S}$ \\
\hline$\beta$-alanine & 0.24 & 2.48 & 4.74 & $\mathrm{~S}$ \\
\hline Formamide & 0.20 & 1.62 & 4.76 & $\mathrm{~S}$ \\
\hline Ammonium tartrate & 0.17 & 3.23 & 4.30 & $\mathrm{~S}$ \\
\hline L-proline & 0.17 & 2.44 & 3.93 & $\mathrm{~S}$ \\
\hline Sodium nitrate & 0.16 & 2.66 & 4.90 & $\mathrm{~S}$ \\
\hline Urea & 0.15 & 1.16 & 5.22 & $\mathrm{~S}$ \\
\hline Glycine & 0.12 & 3.20 & 3.98 & $\mathrm{~S}$ \\
\hline Glutamic acid & 0.11 & 2.21 & 4.76 & $\mathrm{~S}$ \\
\hline L-alanine & 0.10 & 2.15 & 4.11 & $\mathrm{~S}$ \\
\hline L-serine & 0.10 & 1.62 & 3.95 & $\mathrm{~S}$ \\
\hline L-citrulline & 0.09 & 2.58 & 3.44 & $\mathrm{E}$ \\
\hline Trans-hydroxy-L-proline & 0.09 & 1.01 & 3.69 & $\mathrm{~S}$ \\
\hline L-asparagine & 0.08 & 3.49 & 3.83 & $\mathrm{~F}$ \\
\hline L-histidine & 0.08 & 2.02 & 3.54 & $\mathrm{~S}$ \\
\hline Glutamine & 0.08 & 3.48 & 3.88 & $\mathrm{~S}$ \\
\hline Arginine & 0.04 & 2.68 & 3.28 & $\mathrm{~S}$ \\
\hline L-cysteine monohydrochloride & 0.04 & 1.57 & 4.75 & $\mathrm{~N}$ \\
\hline L-threonine & 0.03 & 0.90 & 3.68 & $\mathrm{~S}$ \\
\hline Putrescine dihydrochloride & 0.01 & 1.46 & 2.42 & $\mathrm{~S}$ \\
\hline Aspartic acid & 0.01 & 3.33 & 4.99 & $\mathrm{~S}$ \\
\hline Potassium nitrite & 0.00 & 0.49 & 6.18 & $\mathrm{~F}$ \\
\hline L-methionine & 0.00 & 0.93 & 3.33 & $\mathrm{~S}$ \\
\hline Anthranilic acid & 0.00 & 0.60 & 5.68 & $\mathrm{~S}$ \\
\hline $\operatorname{LSD}(P \leq 0.05)$ & 1.34 & 1.31 & 0.31 & $\ldots$ \\
\hline
\end{tabular}

a In 5.5-cm-diameter petri dish $\left(\times 10^{8}\right)$.

b Measured as $\mathrm{g} / \mathrm{ml}\left(\times 10^{-3}\right)$.

${ }^{c} \mathrm{E}=$ Eastman Kodak Co. (Rochester, NY), F = Fisher Scientific Co. (Pittsburgh), $\mathrm{N}=$ National Biochemicals (Cleveland), and $\mathrm{S}=$ Sigma Chemical Co. (St. Louis).
2 min and then further mixed with $54 \mathrm{~kg}$ of soil in a large cement mixer for $4 \mathrm{~min}$. Each eggplant was transplanted into a $16-\mathrm{cm}-\mathrm{di}-$ ameter pot containing $3 \mathrm{~kg}$ of $\mathrm{V}$. dahliae-infested, nonsterile field soil or noninfested soil (healthy control).

Incidence of $V$. dahliae in an eggplant was determined by a series of petiole samplings beginning with the onset of wilt symptoms. Beginning 3 weeks after transplant, plants were examined every 3 to 4 days for symptoms. For plants exhibiting wilt symptoms, the bottom two leaf petioles were removed from an eggplant, surfacedisinfected with $0.5 \% \mathrm{NaOCl}$, and divided into $0.5-\mathrm{cm}$ sections. Three sections per petiole were plated on a 9-cm-diameter petri dish containing $20 \mathrm{ml}$ of a medium semiselective for $V$. dahliae (1). Petiole sections were incubated in the dark at $21^{\circ} \mathrm{C}$ and examined daily for the presence of hyphae in the vascular tissues. When vascular colonization occurred, infected petioles were incubated until $V$. dahliae microsclerotia formed. At 41 and 45 days after transplanting in experiments 1 and 2, respectively, all remaining eggplants were assayed for $V$. dahliae. The experiment was repeated once.

Because of the binary nature of the data (wilted or not wilted for each plant for each day), statistical methods usually used in plant pathology could not be used to analyze these data. Hence, differences among treatments were determined by producing Kaplan-Meier product limit estimates (9), which are used routinely in medical clinical survivorship studies. We have previously used this method to study the effect of various formulations of $T$. flavus on suppression of Verticillium wilt (5). This survivor analysis was employed using the SAS lifetest procedure (SAS Institute, Inc.). Gehan's (6) generalized Wilcoxon test was then used to compare survival curves of the various treatment groups and to determine if there were block effects or differences between the two experiments.

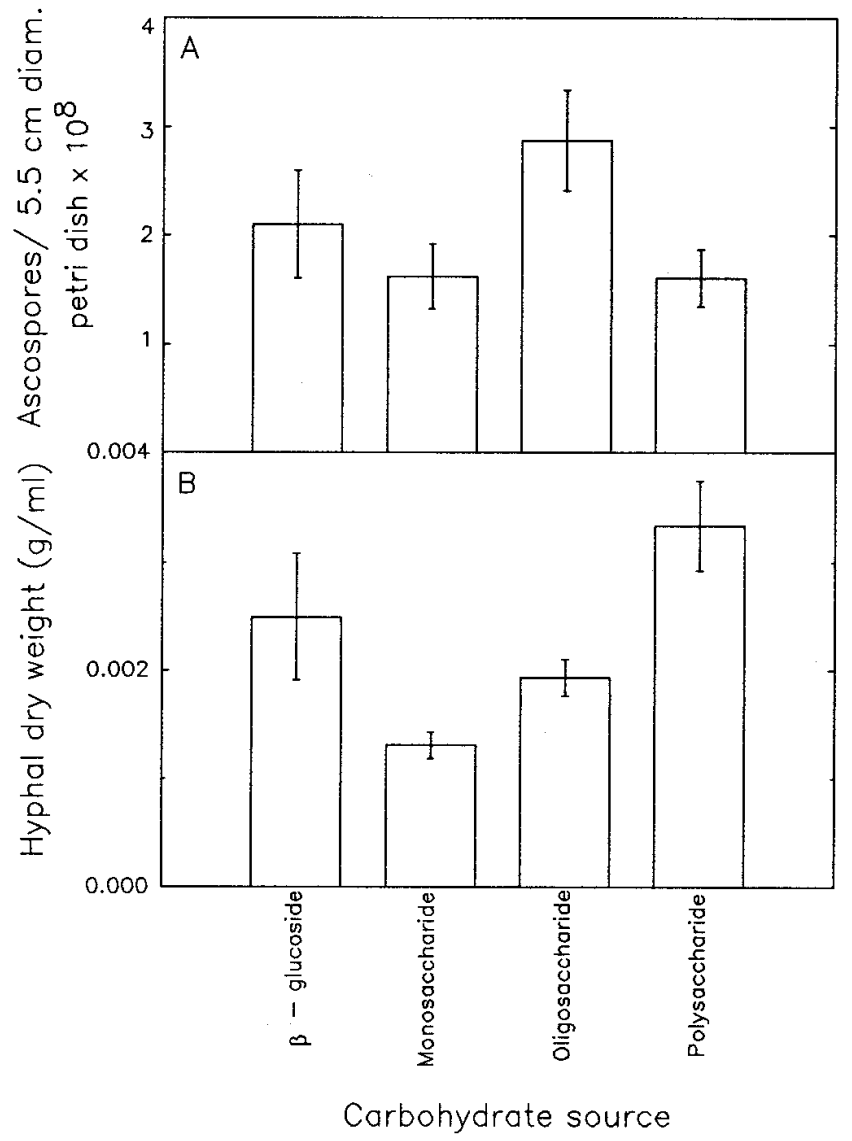

Fig. 1. Production of $\mathbf{A}$, ascospores and $\mathbf{B}$, biomass of Talaromyces flavus on various classes of carbon compounds. Error bars represent $95 \%$ confidence intervals. 


\section{RESULTS}

C sources. The various $\mathrm{C}$ sources yielded $10^{6}$ to $10^{8}$ ascospores of T. flavus per 5.5-cm-diameter petri dish after 5 days of incubation and $10^{-3}$ to $10^{-4} \mathrm{~g}$ of hyphal dry weight per milliliter of liquid medium (Table 1). Twelve and eight of the $37 \mathrm{C}$ sources yielded final ascospore numbers and hyphal dry weights, respectively, greater than the treatment containing no $\mathrm{C}$ source (Table 1). In general, production of hyphae was greatest on the more complex sugars such as polysaccharides and $\beta$-glucosides, and was least on monosaccharides (Fig. 1 and Table 1). However, the greatest number of ascospores was produced on oligosaccharides and the fewest on monosaccharides and polysaccharides (Fig. 1A and B and Table 1). Overall, there was no significant correlation between production of ascospores and hyphal dry weight, and this relationship varied dramatically among $\mathrm{C}$ sources. Some $\mathrm{C}$ sources, such as cellulose Type 20, phloridzin, and cellobiose, supported high levels of production of both ascospores and hyphae (Table 1). For other C sources, such as lactose monohydrate, glycerol, and arbutin, high numbers of ascospores and low levels of hyphae were produced. Although a direct comparison between liquid and solid media can not be made, these data suggest an inverse relationship between production of ascospores and production of hyphae (Table 1). Still other $C$ sources, such as phenyl- $\beta$-D-glucoside, polygalacturonic acid, and salicin, resulted in high biomass weights and low ascospore production. In fact, lactose monohydrate supported the greatest production of ascospores, but the least hyphal weight of all $\mathrm{C}$ sources. Final $\mathrm{pH}$ of the media ranged from 3.90 to 6.54 and was not correlated with ascospore or biomass production.

$\mathbf{N}$ sources. The various $\mathrm{N}$ sources yielded 0 to $10^{9}$ ascospores per 5.5-cm-diameter petri dish and $10^{-4}$ to $10^{-5} \mathrm{~g}$ of hyphal dry weight per milliliter of liquid medium (Table 2). Eleven and 28 of the $\mathrm{N}$ sources resulted in ascospore numbers and hyphal dry weights, respectively, significantly greater than the treatment without a $\mathrm{N}$ source (Table 2). In general, $\mathrm{N}$ sources that resulted in the greatest number of ascospores also yielded the greatest hyphal dry weight. However, this relationship varied with individual $\mathrm{N}$ sources. Sources such as uric acid, tyrosine, and hypoxanthine produced high levels of both ascospores and hyphae, significantly greater than that with no $\mathrm{N}$ source; whereas threonine, methionine, and anthranilic acid produced levels of both ascospores and hyphae comparable with or less than that of no $\mathrm{N}$ source. Other $\mathrm{N}$ sources, such as adenine, alanine, and ammonium tartrate, produced high biomass levels, but very low ascospore numbers. Unlike with $\mathrm{C}$ sources, when no $\mathrm{N}$ source was added to the medium, moderate numbers of ascospores, but little biomass, were produced. However, there was no $\mathrm{N}$ source tested that resulted in high numbers of ascospores and low biomass. Final $\mathrm{pH}$ of the media ranged from 2.71 to 6.18 and was not correlated with ascospore or biomass production.

Daily biomass production and media $\mathbf{p H}$. There was no significant difference between cultures at ambient versus $27^{\circ} \mathrm{C}$ in daily biomass production or in $\mathrm{pH}$ for $\mathrm{C}$ or $\mathrm{N}$ sources; data presented are for $27^{\circ} \mathrm{C}$. Biomass production in the $\mathrm{C}$ sources xylan, gum ghatti, and maltose increased over time and was significantly greater $(P \leq 0.05)$ than in the other $\mathrm{C}$ sources, whereas biomass production in glycerol, sorbose, and lactose was not different $(P \leq$ 0.05 ) from the control treatment with no $\mathrm{C}$ source (Fig. 2A). The $\mathrm{pH}$ of the media was also significantly affected by the $\mathrm{C}$ source (Fig. 2B). The $\mathrm{pH}$ values in media with maltose, sorbose, and gum ghatti decreased over time, and all treatments except glycerol were significantly $(P \leq 0.05)$ lower than in the treatment with no C source.
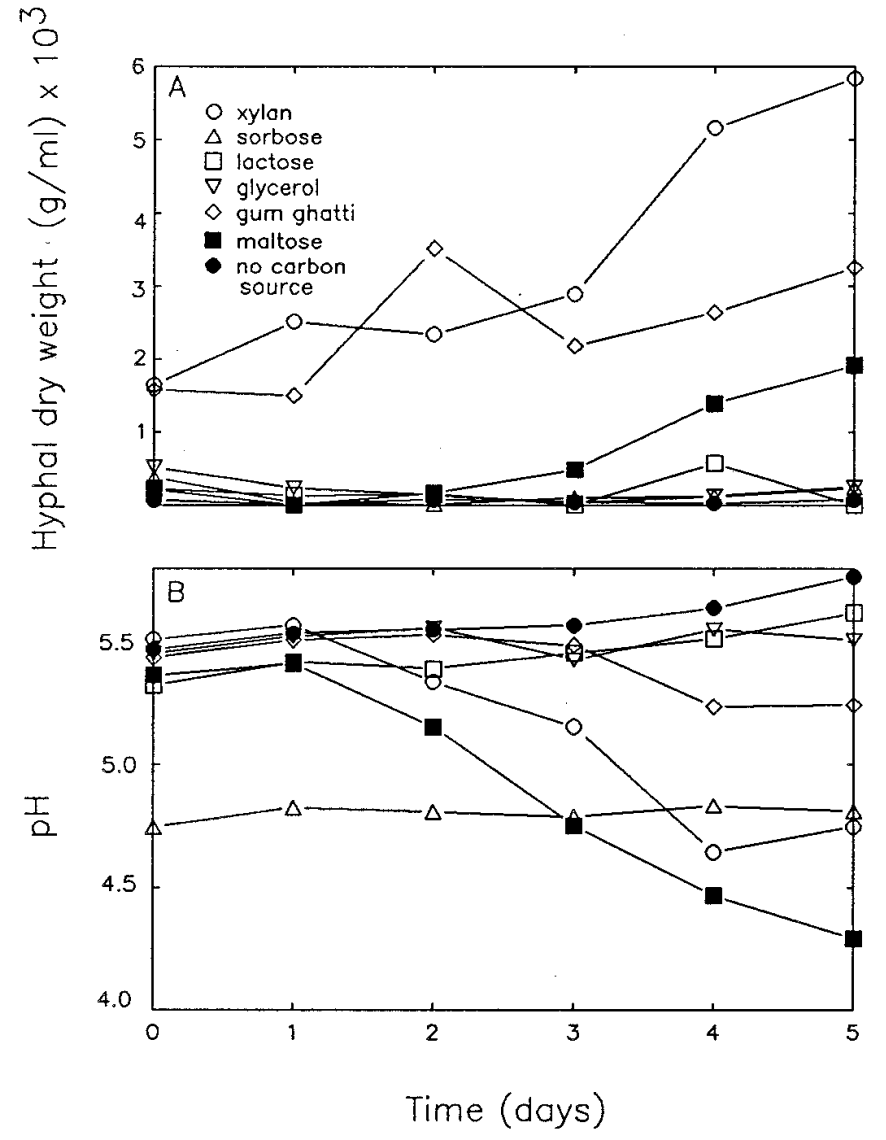

Fig. 2. A, Production of biomass of Talaromyces flavus and $\mathbf{B}$, alterations in medium $\mathrm{pH}$ in liquid media amended with selected carbon sources.

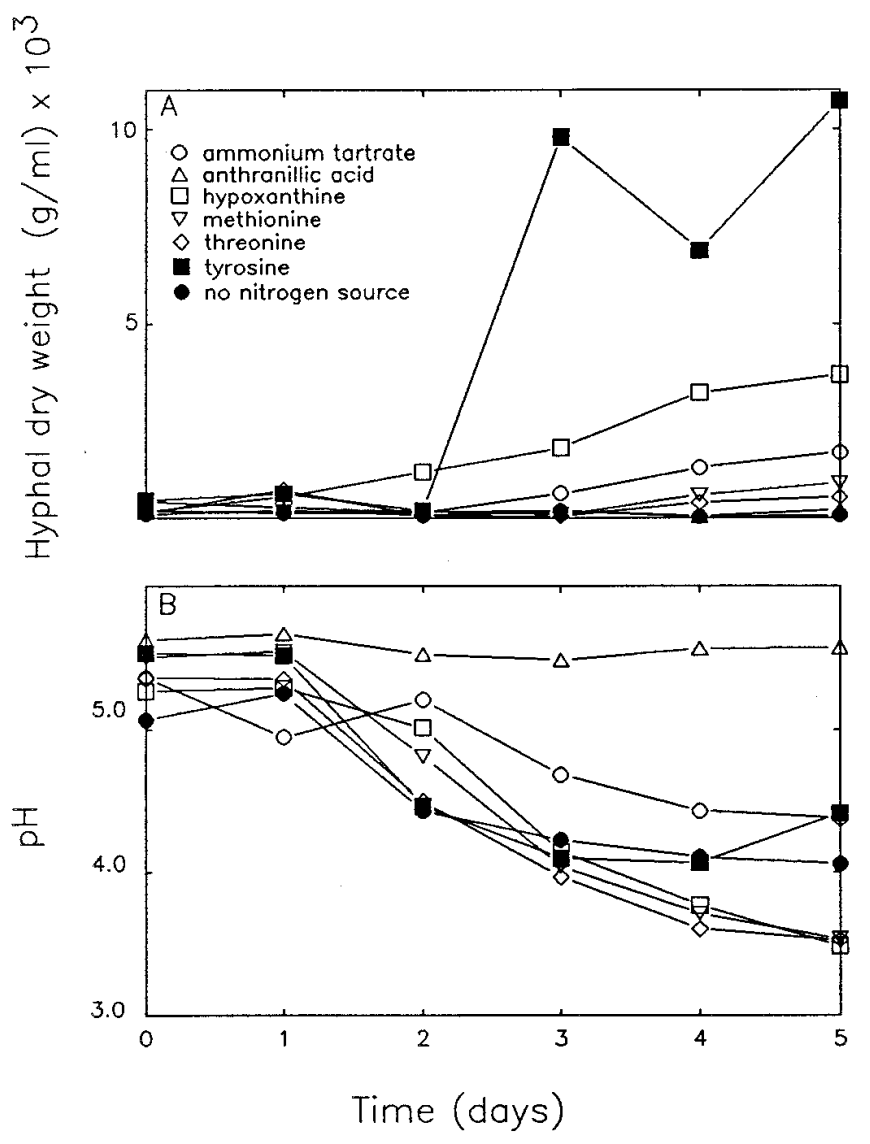

Fig. 3. A, Production of biomass of Talaromyces flavus and $\mathbf{B}$, alterations in medium $\mathrm{pH}$ in liquid media amended with selected nitrogen sources. 
Biomass in the $\mathrm{N}$ source tyrosine was significantly greater than in all other treatments over time $(P \leq 0.05)$, but biomass produced in ammonium tartrate, methionine, threonine, and anthranilic acid was not different from the treatment without $\mathrm{N}(P \leq 0.05)$ (Fig. $3 \mathrm{~A})$. The $\mathrm{pH}$ of all treatments, except anthranilic acid, decreased over time, and overall the $\mathrm{pH}$ in anthranilic acid and ammonium tartrate was greater than in other treatments $(P \leq 0.05)$ (Fig. 3B). There was no correlation between $\mathrm{pH}$ and the amount of hyphal biomass produced for either $\mathrm{C}$ or $\mathrm{N}(P \leq 0.05)$.

$C: N$ ratio and PDA. The ratio of $C$ to $N$ significantly affected the yield of both hyphal dry weight and ascospores, although those effects depended on the $\mathrm{N}$ source used (Fig. 4A and B). At low $\mathrm{C}: \mathrm{N}$ ratios $(<15: 1)$, treatments with hypoxanthine as a $\mathrm{N}$ source resulted in significantly greater production of biomass and hyphae than treatments with ammonium tartrate (Fig. 4A and B). However, at $\mathrm{C}: \mathrm{N}$ ratios of 15:1 or greater, there was no difference due to $\mathrm{N}$ source. Hyphal dry weight decreased as the $\mathrm{C}: \mathrm{N}$ ratio increased from 5:1 to 30:1 with hypoxanthine as the $\mathrm{N}$ source, but stayed the same when ammonium tartrate was the $\mathrm{N}$ source. In contrast, greater numbers of ascospores were produced as the $\mathrm{C}: \mathrm{N}$ ratio increased over this same range for both $\mathrm{N}$ sources. Although the production of ascospores and biomass was different between the two $\mathrm{C}$ sources (maltose and lactose), the overall response to $\mathrm{C}: \mathrm{N}$ ratios was the same as for both $\mathrm{C}$ sources. $T$. flavus produced $3.47 \times 10^{-3} \mathrm{~g}$ of hyphal dry weight per milliliter of liquid medium after 3 days in potato dextrose broth and produced $7.83 \times 10^{9}$ per 5.5-cm-diameter petri dish ascospores after 6 weeks on PDA.

Biocontrol efficacy. Median times for wilt development were used as one estimate of disease progress. The median time for wilt development is the number of days after transplanting into pathogen-infested soil when half of the plants in a treatment were wilted. Only treatments with ascospores produced on PDA $(P \leq$ $0.01)$ and the nontreated healthy control $(P \leq 0.01)$ had median times for wilt development significantly greater than the treatment
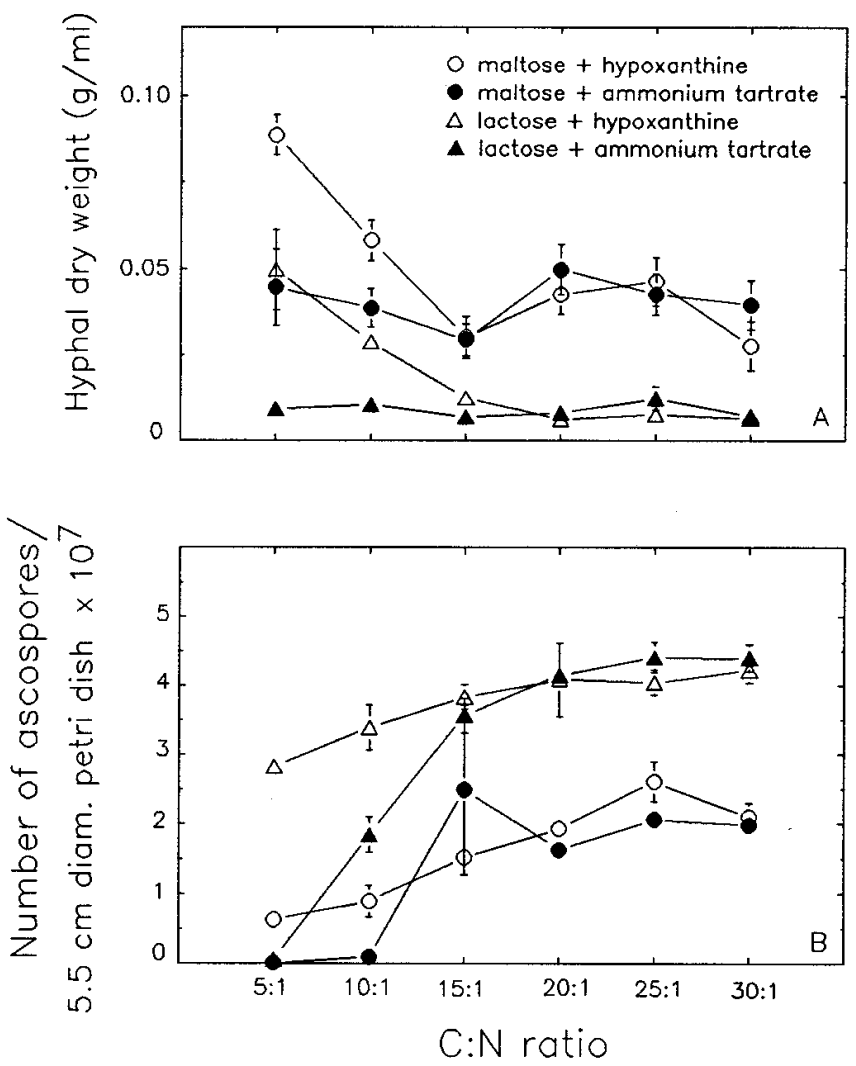

Fig. 4. Production of $\mathbf{A}$, biomass and $\mathbf{B}$, ascospores of Talaromyces flavus on two carbon $(\mathrm{C})$ and two nitrogen $(\mathrm{N})$ sources at various $\mathrm{C}: \mathrm{N}$ ratios. Error bars represent $95 \%$ confidence intervals. with $V$. dahliae alone (disease control treatment), indicating that only ascospores grown on PDA were able to delay the onset of wilt (Fig. 5). However, all treatments had median wilt times less than the nontreated healthy control $(P \leq 0.01)$. In one run of the greenhouse experiment, $V$. dahliae was recovered from one plant in the noninoculated healthy control treatment (Fig. 5). This was likely either due to the use of nonsterile field soil in the test, or to cross contamination from pots receiving $V$. dahliae, since pots were touching.

\section{DISCUSSION}

Biomass and ascospore production were greatly affected by growing $T$. flavus on different $\mathrm{C}$ and $\mathrm{N}$ sources. However, increases in biomass due to $\mathrm{C}$ or $\mathrm{N}$ did not necessarily result in increased ascospore production. On the contrary, many $\mathrm{C}$ sources and $\mathrm{N}$ sources demonstrated an inverse relationship between biomass and ascospore production. Although, in general, ascospore production was greatest on polysaccharides, individual C sources demonstrated great variability in their effects on these growth factors, regardless of the class of $\mathrm{C}$ source.

Biomass and ascospore production were also affected by the $\mathrm{C}: \mathrm{N}$ ratio of the growth medium, and the extent of these effects also depended on the $\mathrm{N}$ source used, particularly at low $\mathrm{C}: \mathrm{N}$ ratios. In general, ascospore production increased with increasing $\mathrm{C}: \mathrm{N}$, but hyphal dry weight decreased or was not affected, depending on the $\mathrm{N}$ source.

Results of the greenhouse biocontrol assay indicated that choice of the media on which biocontrol fungi are produced greatly impacts the efficacy of the biocontrol agent. T. flavus produced 3.83 $\times 10^{10}$ ascospores per 5.5-cm-diameter petri dish on lactose + hypoxanthine, $1.52 \times 10^{10}$ ascospores per dish on maltose + hypoxanthine, and $7.83 \times 10^{9}$ ascospores per dish on PDA; yet, ascospores produced on PDA were significantly more effective in delaying the onset of wilt. Thus, nutrients present during production of the ascospores affected not only the number of spores produced, but also the efficacy of these spores in reducing Verticillium wilt. Accordingly, optimum conditions for production of biocontrol agents of maximum efficiency may not necessarily be the conditions that support the greatest populations of propagules or the greatest production of fungal biomass. Similarly, culture media influence the efficacy of the mycoherbicide Colletotrichum truncatum $(2,7,11)$. Schisler et al. (11) reported that the C:N ratio of the production medium influenced efficacy of $C$. truncatum, as well as the number of conidia produced and their morphology. A C:N ratio of 30:1 resulted in the greatest number of conidia, and conidia grown at a $\mathrm{C}: \mathrm{N}$ ratio of 10:1 were longer and thinner than those

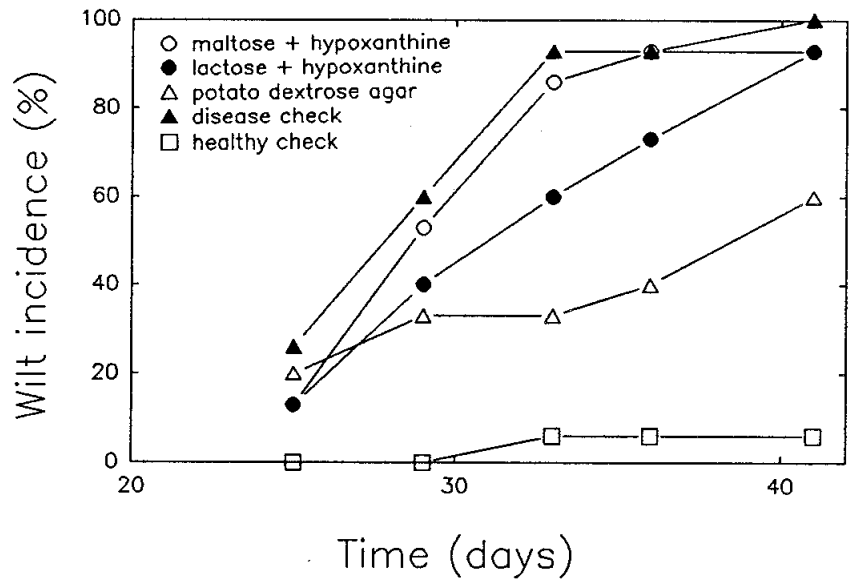

Fig. 5. Effect of ascospores of Talaromyces flavus produced on defined nutrient sources and potato dextrose agar on incidence of Verticillium wilt in a greenhouse test in field soil. 
produced at C:N ratio $30: 1$ or $80: 1$. Conidia grown at 10:1 C:N ratio were more successful at initiating disease in the weed hemp sesbania (Sesbania exaltata) than those grown at 30:1 or $80: 1$. Subsequent work indicated that conidia produced at 10:1 contained significantly more protein and less lipid than those produced at $30: 1$ or $80: 1$.

Nutrients in the formulation can also affect biocontrol efficacy. For example, T. flavus formulated in alginate prill with either pyrophyllite or ground corn cobs delayed onset of Verticillium wilt, while $T$. flavus formulated with milled chitin, fish meal, neem cake, peanut hulls, soy fiber, or wheat bran did not (5).

Our data indicate that there are complex relationships involving nutrient sources and the growth and efficacy of T. flavus as a biocontrol agent. Since, in this study, only a few media were tested for their effects on biocontrol efficacy, no definitive conclusions can be drawn regarding the best nutrient source to use to provide maximum biocontrol efficacy. However, the data suggest that it may be possible to enhance the level of control through manipulation of nutrient sources present during production of the antagonist. It is clear that the role of the nutrient source can be critical to the success of a biocontrol agent, and must be evaluated to ensure reasonable efficacy. More work is needed to determine which nutrient sources may provide the optimum balance of production of propagules and biocontrol efficacy. Additional work is also needed to determine whether the relationship of the nutritional status of the antagonists and biocontrol ability is due to a specific phenomenon or to a physiological state, such as induction of glucose oxidase involved in the mechanism of biocontrol (13), or whether it is due to a more general lack of ecological fitness.

\section{ACKNOWLEDGMENTS}

This research was supported by BARD grant US-1740-89. We thank J. Chittams, Biometrical Consulting Services, USDA, ARS, Beltsville, MD, for assistance in analyzing data from the greenhouse test.

\section{LITERATURE CITED}

1. Ausher, R., Katan, J., and Ovadia, S. 1975. An improved selective medium for the isolation of Verticillium dahliae. Phytoparasitica 3:133-137.
2. Daigle, D. J., and Cotty, P. J. 1994. Stability of Colletotrichum truncatum in culture influences mycoherbicide efficacy. Mycologia 86:397-400.

3. Davis, J. R., Fravel, D. R., Marois, J. J., and Sorenson, L. H. 1986. Effect of soil fumigation and seedpiece treatment with Talaromyces flavus on wilt incidence and yield, 1983. Page 18 in: Biol. Cultural Tests Control Plant Dis. 1.

4. Fravel, D. R., Kim, K. K., and Papavizas, G. C. 1987. Viability of microsclerotia of Verticillium dahliae reduced by a metabolite produced by Talaromyces flavus. Phytopathology 77:616-619.

5. Fravel, D. R., Lewis, J. A., and Chittams, J. L. 1995. Alginate prill formulations of Talaromyces flavus with organic carriers for biocontrol of Verticillium dahliae. Phytopathology 85:165-168.

6. Gehan, E. A. 1965. A generalized Wilcoxon test for comparing arbitrarily singly-censored samples. Biometrika 52:203-223.

7. Jackson, M. A., and Schisler, D. A. 1992. The composition and attributes of Colletotrichum truncatum spores are altered by the nutritional environment. Appl. Environ. Microbiol. 58:2260-2265.

8. Johnson, W. M., Johnson, E. K., and Brinkerhoff, L. A. 1980. Symptomology and formation of microsclerotia in weeds inoculated with Verticillium dahliae from cotton. Phytopathology 70:31-35.

9. Kaplan, E. L., and Meier, P. 1958. Nonparametric estimation from incomplete observations. J. Am. Stat. Assoc. 53:457-481.

10. Marois, J. J., Johnston, S. A., Dunn, M. T., and Papavizas, G. C. 1982. Biological control of Verticillium wilt of eggplant in the field. Plant Dis. 66:1166-1168.

11. Schisler, D. A., Jackson, M. A., and Bothast, R. J. 1991. Influence of nutrition during conidiation of Colletotrichum truncatum on conidial germination and efficacy in inciting disease in Sesbania exaltata. Phytopathology 81:587-590.

12. Shirling, E. B., and Gottlieb, D. 1966. Methods for characterization of Streptomyces species. Int. J. Syst. Bacteriol. 16:313-340.

13. Stosz, S. K., Fravel, D. R., and Roberts, D. P. 1996. In vitro analysis of the role of glucose oxidase from Talaromyces flavus in biocontrol of Verticillium dahliae. Appl. Environ. Microbiol. 62:3183-3186.

14. Tjamos, E. C., Biris, D. A., and Paplomatas, E. J. 1991. Recovery of olive trees with Verticillium wilt after individual application of soil solarization in established olive orchards. Plant Dis. 75:557-562.

15. Tjamos, E. C., and Fravel, D. R. 1997. Distribution and establishment of the biocontrol fungus Talaromyces flavus in soil and on roots of solanaceous crops. Crop Prot. 16:135-139.

16. Tjamos, E. C., and Paplomatas, E. J. 1987. Effect of solarization on the survival of fungal antagonists of Verticillium dahliae. EPPO (Eur. Mediterr. Plant Prot. Organ.) Bull. 17:645-653.

17. Tjamos, E. C., and Paplomatas, E. J. 1988. Long-term effect of soil solarization in controlling Verticillium wilt of globe artichokes in Greece. Plant Pathol. 37:507-515. 